\title{
Aktivitas Antibakteri Ekstrak Tangkai dan Daun Begonia Multangula Blume. terhadap Porphyromonas Gingivalis
}

\section{Antibacterial Activity of Begonia multangula Blume. Stem and Leaf Extract on Porphyromonas gingivalis}

\author{
Nadya Haqque Santosa Putri ${ }^{1) *}$, Dewi Nurdiwiyati ${ }^{1)}$, Sintia Lestari'²), Billyardi Ramdhan ${ }^{1)}$, \\ Muhammad Efendi ${ }^{3)}$, Novik Nurhidayat ${ }^{4}$
}

\author{
${ }^{1}$ Program Studi Pendidikan Biologi, FKIP Universitas Muhammadiyah Sukabumi, Sukabumi, \\ Indonesia \\ ${ }^{2}$ Program Studi Kimia, FSAINTEK Universitas Muhammadiyah Sukabumi, Sukabumi, Indonesia \\ ${ }^{3}$ Balai Konservasi Tumbuhan Kebun Raya Cibodas LIPI, Cianjur, Indonesia \\ ${ }^{4}$ Pusat Penelitian Biologi LIPI, Cibinong, Indonesia \\ *Koresponden: ndyahaq@gmail.com
}

\begin{abstract}
Begonia multangula Blume. has acid sensation and it spread abundant on the western mountains of Java. While result of Periodontitis sufferer's krevicular epitel investigation shows Porphyromonas gingivalis sticking portion are 5-20 times greater than another bacteria. Research about antibacterial activity of the stem and leaf extracts of B. multangula on $P$. gingivalis has been studied. This research using two methods of extraction i.e fresh extract and maseration with etanol and aquades as solvent. Volume extract tested are $10 \mu \mathrm{L}$ and $20 \mu \mathrm{L}$ with aquades and etanol $48 \%$ as negative control. This research using disk difution method with three replications. Incubation process during 40 hours in anaerob jar $37{ }^{\circ} \mathrm{C}$ degree. The results showed that all of the extracts have bactericide activity toward $P$. gingivalis, while two negative controls has no show mentioned bactericide activity. The biggest bactericide activity owned by etanol extract of $B$. multangula's stem, while the smallest bactericide activity owned by aquades extract of $B$. multangula's leaf. Obstruction Power Index (Indeks Daya Hambat, IDH) of all extract inclined low.
\end{abstract}

Keywords: antibacteria, Begonia multangula Blume., fresh extract, maseration, Porphyromonas gingivalis

\section{Pendahuluan}

Prevalensi penyakit Periodontal telah mencapai $60 \%$ pada masyarakat di Indonesia dan menduduki peringkat kedua setelah Karies (Departemen Kesehatan Republik Indonesia, 2010). Penyakit Periodontal biasanya berawal dari penumpukan plak dan bakteri, dimana bakteri yang paling banyak ditemukan ialah Porphyromonas gingivalis (Kaawoan et al., 2016). Hal ini sesuai dengan hasil pemeriksaan perlekatan bakteri pada epitel krevikular penderita Periodontitis yang menunjukkan porsi $P$. gingivalis 5 - 20 kali lebih besar daripada bakteri lainnya. (Nasutiano, 2007)

$P$. gingivalis merupakan bakteri Gram negatif (-) anaerob obligat yang biasa bersembunyi di dalam jaringan periodontal atau sub-gingiva mulut manusia (Samaranayake, 2012 dalam Karima, 2015). P. gingivalis dapat menghasilkan gas berbau berupa Volatile 
Jurnal Biologi Universitas Andalas (J. Bio. UA.)

7(1) - Maret 2019: 51-58 (ISSN : 2303-2162)

Sulphur Compounds (VSC) yang merupakan penyebab utama bau mulut saat jumlahnya berlebihan. Pembentukan VSC didukung oleh suasana mulut yang basa, sementara pada suasana asam, pembentukan VSC terhambat (Widagdo dan Suntya, 2007).

Hasil penelitian Siregar et al. (2009) dalam Indrakumar et al. (2014) menunjukkan bahwa Begonia sp. mempunyai aktivitas antibakteri terhadap Staphylococcus aureus dan Escherichia coli. Hasil penelitian lain menunjukkan bahwa tanaman tersebut mengandung senyawa golongan fenol, flavanoid, steroid, terpenoid dan alkaloid (Ngazizah et al., 2016). Begonia merupakan spesies endemik yang cenderung mudah punah karena memiliki area distribusi dan adaptasi terbatas (Siregar, 2017).

Pemanfaatan dan penelitian yang belum maksimal mengenai bioprospeksi Begonia memunculkan inisiatif untuk menguji aktivitas antibakteri dari salah satu spesies Begonia, yaitu Begonia multangula Blume. terhadap $P$. gingivalis. Hal ini berkaitan dengan rasanya yang asam (Siregar, 2017), fitokimia umum yang dikandung oleh Begonia, dan persebarannya yang melimpah di pegunungan Jawa bagian barat (Wiriadinata et al., 2002; Efendi et al., 2017; Efendi, 2019).

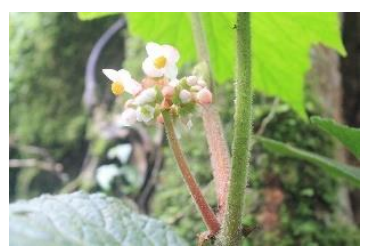

(A)

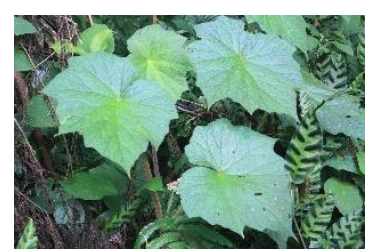

(B)
Gambar 1. Tangkai dan Buah (A) serta Daun Begonia multangula Blume. Sumber: Balai Konservasi Tumbuhan Kebun Raya Cibodas LIPI, Cianjur

\section{Metode Penelitian}

Penelitian ini dilakukan pada April - Juli 2018. Proses ekstraksi Tangkai dan Daun $B$. multangula Blume. dilakukan di Laboratorium Biologi Universitas Muhammadiyah Sukabumi, Sukabumi. Sementara pengujian aktivitas antibakteri dilakukan di Laboratorium
Mikrobiologi dan Kesehatan Pusat Penelitian Biologi LIPI, Cibinong.

\section{Alat dan Bahan}

Alat dan bahan yang digunakan adalah alat dan bahan untuk ekstraksi dan pengujian aktivitas antibakteri. Objek yang digunakan adalah tangkai dan daun B. multangula Blume. koleksi Kebun Raya Cibodas LIPI, Cianjur, Jawa Barat yang diambil pada bulan Mei 2018 (Gambar 1) dan kultur bakteri $P$. gingivalis dari Laboratorium Mikrobiologi kesehatan Pusat Penelitian Biologi LIPI, Cibinong, Jawa Barat yang dibiakkan pada bulan Mei 2018.

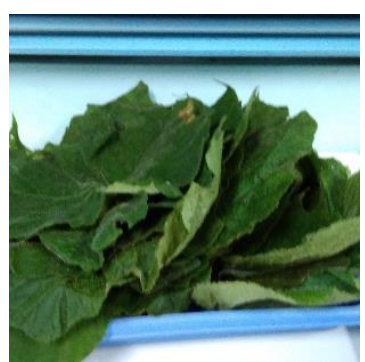

(A)

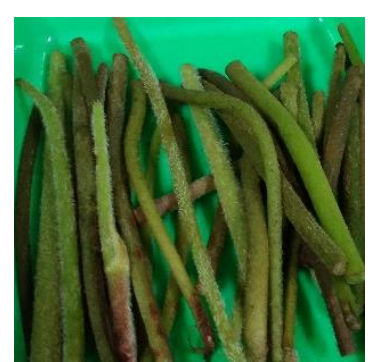

(B)
Gambar 2. Daun (A) dan Tangkai (B) Begonia multangula Blume. dewasa yang telah dipotong dan dicuci.

\section{Proses Ekstraksi}

Proses ekstraksi dilakukan dengan dua cara, yaitu ekstrak segar dan maserasi. Ekstrak segar digunakan untuk menjaga fitokimia yang berkemungkinan rusak apabila diberikan pemanasan dengan sinar matahari.

Untuk membuat ekstrak segar, sebanyak 200 g Tangkai dan Daun $B$. multangula Blume. (Gambar 2) dicuci sampai bersih, kemudian dipotong dan diblender sampai halus. Diberikan pula penambahan aquades $( \pm 2 \mathrm{~mL}$ ). Hasil blender diperas, kemudian dipisahkan ekstrak cair dan padatnya menggunakan kertas saring. Ekstrak disimpan di dalam botol hitam pada suhu ruang hingga dilakukan pengujian.

Ekstraksi kedua dilakukan dengan cara maserasi. Tangkai dan Daun B. multangula 
Blume. dicuci sampai bersih lalu dipotong dengan ketebalan 1 - $2 \mathrm{~mm}$. Tangkai dan daun yang telah dipotong kemudian dijemur di bawah sinar matahari tidak langsung selama \pm 10 jam. Hasil penjemuran kemudian dioven selama \pm 10 menit dengan suhu $70{ }^{\circ} \mathrm{C}$. Tangkai dan daun yang telah kering kemudian dihaluskan menggunakan blender. Sebanyak 10 $\mathrm{g}$ dari masing-masing simplasia kemudian direndam dalam $100 \mathrm{~mL}$ aquades dan $100 \mathrm{~mL}$ etanol 96\% selama $3 \times 24$ jam pada suhu ruang tanpa cahaya matahari.

Pada 24 jam pertama dan kedua, pelarut rendaman diganti dengan cara menyaring filtrat terlebih dahulu. Hasil saringan pertama, kedua, dan ketiga disatukan ke dalam wadah untuk kemudian diuapkan pelarutnya menggunakan penanggas $70{ }^{\circ} \mathrm{C}$ hingga diperoleh ekstrak sebanyak setengah dari volume awal.

Enam jenis ekstrak B. multangula yang dihasilkan, antara lain ekstrak etanol tangkai (Et. Tangkai); ekstrak etanol daun (Et. Daun); ekstrak aquades tangkai (Aq. Tangkai); ekstrak aquades daun (Aq. Daun); ekstrak segar tangkai (Sr. Tangkai); dan ekstrak segar daun (Sr. Daun).

\section{Uji Aktivitas Antibakteri}

Sebelumnya, dibuat suspensi bakteri $P$. gingivalis dalam tabung berisi $2 \mathrm{~mL} \mathrm{NaCl} 0.9 \%$ hingga diperoleh nilai optical density (OD) sebesar $1 \pm 0.2$. Kemudian bakteri disebar ke dalam cawan petri berisi medium Brain Heart Infusion (BHI) agar.

Setelah \pm 10 menit, kertas cakram 6 mm diletakkan di atas permukaan medium BHI agar dan biakan $P$. gingivalis dengan jarak yang seimbang. Kemudian enam jenis ekstrak dan dua jenis kontrol negatif (aquades dan etanol 48\%) diteteskan sebanyak masing-masing 10 $\mu \mathrm{L}$ dan $20 \mu \mathrm{L}$ di atas kertas cakram. Replikasi dilakukan sebanyak tiga kali. Pengamatan aktivitas antibakteri dilakukan setelah 40 jam inkubasi dalam anaerob jar $37{ }^{\circ} \mathrm{C}$.
Penggunaan anaerob jar berkaitan dengan penyesuaian lingkungan hidup bagi $P$. gingivalis sebagai bakteri anaerob. Sementara rentang suhu $37{ }^{\circ} \mathrm{C}$ disesuaikan dengan suhu tubuh manusia normal yang merupakan habitat alami $P$. gingivalis.

Penguapan pelarut yang hanya setengahnya dari volume awal dapat menyebabkan masih terdapatnya setengah dari volume awal pelarut di dalam ekstrak. Karena itu kontrol negatif berupa etanol $48 \%$ dibuat untuk memastikan bahwa etanol yang terkandung di dalam ekstrak tidak memberi pengaruh terhadap DDH yang terbentuk.

\section{Analisis Data}

Hasil pengujian aktivitas antibakteri didasarkan pada bentuk zona bening dan Diameter Daya Hambat (DDH) di sekeliling kertas cakram (Ngazizah et al., 2016).

Analisis data dilakukan dengan cara menghitung Standar Deviasi dan Indeks Daya Hambat (IDH) dari rata-rata DDH pada tiga replikasi. Standar Deviasi dihitung menggunakan aplikasi Microsoft Excel sementara IDH dihitung dengan rumus;

$$
\mathrm{IDH}=(\mathrm{DDH}-\mathrm{DDB}): \mathrm{DDB}
$$

$\mathrm{IDH}=$ Indeks Daya Hambat

DDH $=$ Diameter Daerah Hambat

DDB $=$ Diameter Disk Blank (kertas cakram)

\section{Hasil dan Pembahasan}

Keenam jenis ekstrak menunjukkan adanya aktivitas antibakteri yang ditandai dengan zona bening di sekitar kertas cakram, sementara dua jenis kontrol negatif (aquades dan etanol 48\%) tidak menunjukkan hal tersebut. Data hasil penelitian yang diperoleh berupa nilai DDH dari ketiga ulangan beserta perhitungan IDH dari rerata DDH dapat dilihat pada Tabel 1. 
Jurnal Biologi Universitas Andalas (J. Bio. UA.)

7(1) - Maret 2019: 51-58 (ISSN : 2303-2162)

Tabel 1. Diameter Daya Hambat (DDH) dan Indeks Daya Hambat (IDH) ekstrak B. multangula terhadap P. gingivalis setelah inkubasi selama 40 jam

\begin{tabular}{|c|c|c|c|c|c|c|c|c|c|c|}
\hline \multirow{3}{*}{ Ekstrak } & \multicolumn{5}{|c|}{ Volume $10 \mu \mathrm{L}$} & \multicolumn{5}{|c|}{ Volume $20 \mu \mathrm{L}$} \\
\hline & \multicolumn{4}{|c|}{$\mathrm{DDH}(\mathrm{mm})$} & \multirow{2}{*}{ IDH } & \multicolumn{4}{|c|}{$\mathrm{DDH}(\mathrm{mm})$} & \multirow{2}{*}{ IDH } \\
\hline & U1 & $\mathrm{U} 2$ & U3 & Rerata & & U1 & $\mathrm{U} 2$ & $\mathrm{U3}$ & Rerata & \\
\hline Et. Tangkai & 7.50 & 7.70 & 8.00 & 7.73 & 0.29 & 9.50 & 11.00 & 10.00 & 10.17 & 0.69 \\
\hline Et. Daun & 6.50 & 6.00 & 7.00 & 6.50 & 0.08 & 8.00 & 9.00 & 9.00 & 8.67 & 0.44 \\
\hline Aq. Tangkai & 6.00 & 6.30 & 6.20 & 6.17 & 0.03 & 6.00 & 6.30 & 6.40 & 6.23 & 0.04 \\
\hline Aq. Daun & 6.20 & 6.00 & 6.00 & 6.07 & 0.01 & 6.20 & 6.00 & 6.00 & 6.07 & 0.01 \\
\hline Sr. Tangkai & 7.00 & 6.50 & 7.10 & 6.87 & 0.14 & 8.00 & 7.50 & 9.00 & 8.17 & 0.36 \\
\hline Sr. Daun & 8.00 & 7.00 & 7.50 & 7.50 & 0.25 & 10.00 & 9.50 & 10.00 & 9.83 & 0.64 \\
\hline Aquades & 6.00 & 6.00 & 6.00 & 6.00 & 0.00 & 6.00 & 6.00 & 6.00 & 6.00 & 0.00 \\
\hline Etanol $48 \%$ & 6.00 & 6.00 & 6.00 & 6.00 & 0.00 & 6.00 & 6.00 & 6.00 & 6.00 & 0.00 \\
\hline
\end{tabular}

Keterangan: Et, Aq, dan Sr berturut-turut berarti ekstrak etanol, ekstrak aquades, dan ekstrak segar; U1, U2, dan U3 berturut-turut berarti data yang diperoleh dari replikasi pertama, kedua, dan ketiga; IDH dihitung dari rerata DDH setiap jenis ekstrak.

Proses ekstraksi yang dilakukan dengan dua cara, yaitu ekstrak segar dan maserasi dilakukan untuk membandingkan potensi antara masing-masing ekstrak berdasarkan sifat pelarutnya. Etanol diketahui bersifat lebih selektif pada senyawa metabolit sekunder, tidak bereaksi dengan komponen yang diekstraksi, serta memiliki daya absorbsi yang baik (Ritna, et al.,2016); sehingga ekstrak etanol diperkirakan dapat mengandung senyawa alkaloid, glikosida saponin, triterpenoid, steroid, flavonoid, tanin, senyawa polifenol, dan antrakinon (Ningsih, et al., 2016). Aquades merupakan pelarut polar yang dapat mengikat senyawa polar. Sementara ekstrak segar digunakan untuk menjaga fitokimia yang berkemungkinan rusak apabila diberikan pemanasan sinar matahari.

Berdasarkan Tabel 1, dapat diketahui bahwa rentang rerata DDH pada volume $10 \mu \mathrm{L}$ berkisar antara 6.07 - $7.73 \mathrm{~mm}$; dan pada volume $20 \mu \mathrm{L} 6.07$ - $10.17 \mathrm{~mm}$. Ekstrak etanol yang diketahui memiliki kandungan fitokimia yang paling kompleks terbukti memiliki rerata DDH terbesar, yaitu $7.73 \mathrm{~mm}$ (Et. Tangkai) dan $6.50 \mathrm{~mm}$ (Et. Daun) untuk volume $10 \mu \mathrm{L}$; serta $10.17 \mathrm{~mm}$ (Et. Tangkai) dan $8.67 \mathrm{~mm}$ (Et. Daun) untuk volume $20 \mu \mathrm{L}$. Ekstrak segar yang sibuat sebagai upaya untuk menjaga fitokimia yang berkemungkinan rusak dengan pemanasan memiliki rerata DDH terbesar kedua, yaitu $6.87 \mathrm{~mm}$ (Sr. Tangkai) dan 7.50 mm (Sr. Daun) untuk volume $10 \mu \mathrm{L}$; serta 8.17 mm (Sr. Tangkai) dan $9.83 \mathrm{~mm}$ (Sr. Daun) untuk volume $20 \mu \mathrm{L}$. Kemudian ekstrak aquades yang hanya mengandung fitokimia polar memiliki rerata DDH terrendah, yaitu $6.17 \mathrm{~mm}$ (Aq. Tangkai) dan $6.07 \mathrm{~mm}$ (Aq. Daun) untuk volume $10 \mu \mathrm{L}$; serta $6.23 \mathrm{~mm}$ (Aq. Tangkai) dan $6.07 \mathrm{~mm}$ (Aq. Daun) untuk volume $20 \mu \mathrm{L}$. Adapun kedua jenis kontrol negatif tidak menunjukkan adanya daya hambat dengan rerata DDH $6.00 \mathrm{~mm}$, sama seperti diameter kertas cakram.

Kekuatan aktivitas antibakteri dari suatu ekstrak dapat diketahui dengan melakukan perhitungan IDH berdasarkan DDH. Tabel 1 menunjukkan bahwa aktivitas antibakteri terbesar dimiliki oleh ekstrak etanol tangkai (Et. Tangkai) dengan IDH sebesar 0,29 pada volume $10 \mu \mathrm{L}$ dan 0,69 pada volume 20 $\mu \mathrm{L}$; diikuti oleh ekstrak segar daun (Sr. Daun) dengan IDH sebesar 0,25 pada volume $10 \mu \mathrm{L}$ dan 0,64 pada volume $20 \mu \mathrm{L}$. Sementara itu, aktivitas antibakteri terkecil dimiliki oleh ekstrak aquades daun (Aq. Daun) dengan IDH sebesar 0.01 pada volume $10 \mu \mathrm{L}$ dan 0,03 pada volume $20 \mu \mathrm{L}$; serta ekstrak aquades tangkai (Aq. Tangkai) dengan IDH sebesar 0,01 pada volume $10 \mu \mathrm{L}$ dan 0,04 pada volume $20 \mu \mathrm{L}$.

Nilai IDH yang begitu kecil pada semua jenis ekstrak (antara 0 - 1) menunjukkan bahwa aktivitas antibakteri ekstrak tangkai dan daun B. multangula cenderung lemah. Adapun faktor yang menyebabkan lemah atau tidak adanya kemampuan menekan pertumbuhan bakteri (aktivitas bakterisidal) adalah konsentrasi atau kerapatan sel dari suspensi bakteri yang cukup tinggi. Aktivitas antibakteri juga dapat dipengaruhi oleh sifat-sifat bakteri 
Jurnal Biologi Universitas Andalas (J. Bio. UA.)

7(1) - Maret 2019: 51-58 (ISSN : 2303-2162)

yang meliputi; jenis, umur, kerapatan, dan kondisi dari bakteri (Ningsih et al., 2013).

Ada dua bentuk zona hambat, yaitu zona irradikal dan zona radikal. Zona irradikal menunjukkan pertumbuhan bakteri tidak terhambat seluruhnya, sehingga pada zona tersebut masih terdapat beberapa koloni bakteri yang dapat bertahan atau resisten. Zona radikal adalah zona dimana sama sekali tidak ditemukan adanya pertumbuhan bakteri, artinya pertumbuhan bakteri dihambat seluruhnya atau bakteri cenderung sensitif terhadap bahan uji (Ngazizah, 2016).

Aktivitas antibakteri suatu zat terbagi menjadi dua macam berdasarkan sifat toksisitas selektifnya, yaitu; aktivitas bakteriostatik yang hanya menghambat pertumbuhan bakteri dan aktivitas bakterisida yang dapat benar-benar mematikan bakteri (Ngazizah, 2016). Penalaran lebih lanjut menunjukkan bahwa zona irradikal merupakan indikator dari aktivitas bakteriostatik, sementara zona radikal merupakan indikator aktivitas bakterisida.

Seluruh jenis ekstrak menampilkan zona radikal pada daerah hambat yang terbentuk, sementara kedua jenis kontrol negatif cenderung tidak menunjukkan adanya aktifitas antibakteri terhadap $P$. gingivalis. Hal ini menunjukkan bahwa seluruh jenis ekstrak $B$. multangula Bume. memiliki aktivitas bakterisida terhadap bakteri $P$. gingivalis, yang artinya ekstrak dapat benar-benar mematikan bakteri atau bakteri cenderung sensitif terhadap semua jenis ekstrak tanpa ada pengaruh dari pelarut yang digunakan.

$P$. gingivalis merupakan bakteri Gram (-) anaerob obligat. Struktur dinding sel bakteri Gram (-) lebih kompleks dibandingkan struktur dinding sel bakteri Gram positif (+). Secara umum, dinding sel bakteri terdiri atas tiga lapis yaitu lapisan dalam (peptidoglikan) dan dua lapisan luar (lipopolisakarida dan lipoprotein). Dinding sel bakteri Gram (-) memiliki lapisan peptidoglikan yang lebih tipis dibandingkan bakteri Gram (+), tetapi memiliki lapisan membran luar tambahan yang lebih kompleks, akibatnya secara umum, senyawa aktif akan lebih sulit menembus dinding sel bakteri Gram (-) daripada Gram (+) (Irianto, 2006 dalam Ngazizah et al., 2016)
Perbedaan aktivitas antibakteri dapat dipengaruhi oleh jenis dan konsentrasi senyawa aktif yang tersaring. Keberadaan bahan organik asing di dalam ekstrak pun dapat menurunkan efektifitas senyawa aktif dengan menonaktifkan senyawa aktif tersebut (Ningsih et al., 2013). Selain itu, setiap ekstrak memiliki kemampuan penghambatan yang berbeda-beda. Hal ini disebabkan oleh kandungan senyawa aktif pada masing-masing ekstrak yang cenderung berbeda, tergantung pada tingkat kepolaran pelarut yang digunakan (Ngazizah $e t$ al., 2016). Penelitian ini menggunakan etanol sebagai pelarut karena etanol dapat menarik senyawa non polar, semi polar, dan polar (Nagariya et al., 2010).

Secara umum, hasil uji fitokimia menunjukkan bahwa Begonia mengandung senyawa golongan fenol, flavanoid, steroid, terpenoid dan alkaloid (Siregar et al., 2009 dalam Indrakumar et al., 2014). Di sisi lain, ekstrak etanol dan ekstrak aquades dari Begonia sp. positif mengandung senyawa saponin, alkaloid, senyawa tanin, golongan senyawa fenol, ethyl palmitate; palmitic acid; ethyl linolenat; dan acetol (Ngazizah et al., 2016).

Saponin sebagai antibakteri dapat menyebabkan kerusakan protein dan enzim di dalam sel. Saponin berdifusi melewati peptidoglikan dan dinding sel kemudian mengikat membran dalam yang dapat menyebabkan sitoplasma keluar dari sel proses ini dapat mengakibatkan kematian sel (Taufiq et al., 2015).

Fenol sebagai antibakteri dapat menonaktifkan enzim-enzim di dalam sel juga membuat membran sel lisis (Taufiq et al., 2015). Terjadinya lisis pada membran sel mengakibatkan kebocoran pada sel sehingga metabolit esensial yang dibutuhkan sel keluar. Adapun senyawa fenol di dalam sel akan merusak sistem kerja sel, merusak membran sitoplasma, mendenaturasi protein dan asam nukleat, juga menghambat sintesis protein dan asam nukleat (Novianti, 2015).

Terpenoid sebagai antibakteri dapat bereaksi dengan porin (protein trans-membran) pada membran luar membentuk ikatan polimer yang sangat kuat sehingga mengakibatkan rusaknya porin. Akibatnya permeabilitas 
Jurnal Biologi Universitas Andalas (J. Bio. UA.)

7(1) - Maret 2019: 51-58 (ISSN : 2303-2162)

dinding sel berkurang dan mobilitas nutrisi atau senyawa esensial sel terganggu (Amalia et al., 2014).

Flavonoid sebagai antibakteri bekerja merusak dinding sel karena dapat berikatan dengan protein dan lipid, menggumpalkan protein, merusak dinding sel, dan mengakibatkan sel lisis hingga mati (Monalisa et al., 2011 dalam Karima, 2015). Flavonoid juga dapat mengganggu fungsi metabolisme sel dengan mendenaturasi enzim protease di dalam sel (Ngazizah et al., 2016).

Tanin sebagai antibakteri dapat merusak metabolisme dan permeabilitas bakteri (Newman et al., 2012 dalam Karima, 2015). Tanin juga dapat bereaksi dengan membran sel, menginaktivasi enzim (Karima, 2015), serta mendestruksi fungsi materi genik dengan membentuk kompleks protein melalui ikatan hidrogen dan ikatan hidrofobik (Ningsih, 2013).

Sementara alkaloid sebagai antibakteri mengandung senyawa aromatik kuartener yang sangat tinggi, sehingga di dalam sel dapat membentuk interkhelat dengan DNA, yang meyebabkan sel mengalami mutasi atau kerusakan genetik (Amalia et al., 2014).

Berdasarkan penjelasan di atas, dapat diketahui bahwa sebagian besar senyawa aktif yang dikandung oleh Begonia sangat efektif dalam menyebabkan kerusakan pada sel bakteri.

Penelitian ini tidak mengukur dan menetapkan konsentrasi ekstrak yang digunakan, sehingga sulit diketahui apakah aktivitas antibakteri yang lemah disebabkan oleh sedikitnya konsentrasi ekstrak, tingginya kerapatan bakteri, atau karena kesalahan dalam penelitian; terlebih pada metode ekstraksi yang tidak menggunakan rotatory evaporator untuk menguapkan pelarut.

\section{Kesimpulan}

Ekstrak dari tangkai dan daun B. multangula memiliki aktivitas antibakteri terhadap $P$. gingivalis. Jenis aktivitas yang terbentuk adalah aktivitas bakterisida yang menunjukkan bahwa pertumbuhan bakteri benar-benar terhambat oleh ekstrak. Aktivitas ini ditandai oleh zona radikal yang terbentuk di sekeliling kertas cakram.

Aktivias antibakteri tertinggi dimiliki oleh ekstrak etanol tangkai dan aktivitas antibakteri terendah dimiliki oleh ekstrak aquades daun. Adapun IDH secara keseluruhan cenderung lemah.

\section{Ucapan Terima Kasih}

Terima kasih yang sebesar-besarnya kepada Kementrian RISTEKDIKTI yang telah membiayai program kreativitas mahasiswa bidang penelitian eksak (PKM-PE); Laboratorium Biologi Universitas Muhammadiyah Sukabumi yang telah menyediakan fasilitas dan dukungan moral; Kebun Raya Cibodas LIPI sebagai pemilik sumber daya spesies Begonia multangula Blume. Laboratorium Mikrobbiologi Kesehatan Pusat Penelitian Biologi LIPI sebagai pemilik sumber daya bakteri Porphyromonas gingivalis serta sebagai penyedia fasilitas dan bantuan selama penelitian; Program Studi Pendidikan Biologi UMMI yang telah banyak memberikan bantuan teknis dan administrasi; serta semua pihak yang tidak disebutkan satu persatu.

\section{Daftar Pustaka}

Amalia S., S Wahdaningsih dan N. K. Untari. 2014. Antibacterial Activity Testing of NHexane Fraction of Red Dragon (Hylocereus polyrhizus Britton \& Rose) Fruit Peel on Staphylococcus aureus ATCC 25923. Trad. Med.J Vol 19, No $2: 89$ - 94.

Departemen Kesehatan Republik Indonesia. 2010. Profil Kesehatan Indonesia Tahun 2010. Depkes.go.id: http://www.-depkes.go.id/download.php? file $=$ download/pusdatin/profilkesehatan-indonesia/profil-kesehatanindonesia-2010.pdf. Diakses tanggal 6 Juli 2018.

Efendi, M. 2019. Begonia alam di Kebun Raya Baturaden, Jawa Tengah. Pros Sem Nas Masy Biodiv Ind Vol 5, No 1 : 1317. 
Jurnal Biologi Universitas Andalas (J. Bio. UA.)

7(1) - Maret 2019: 51-58 (ISSN : 2303-2162)

Efendi, M., N. Azizah, A. Supriyatna, dan Destri. 2017. Keragaman Jenis dan Preferensi Ekologi Begonia Liar di Kawasan Hutan Sisa Kebun Raya Cibodas. Berita Biologi Vol 16, No 3 : 233-241

Indrakumar I., R. Gomathi dan S. Karpagam. 2014. Antimicrobial and In vitro Antioxidant Potential of Begonia dipetala Graham. Int J Pharm Sci Rev Res Vol 27, No 2 : 382 - 386.

Irianto K. 2006. Mikrobiologi Menguak Dunia Mikroorganisme Jilid 1. Yrama Widya. Bandung.

Jawetz E., J. L. Melnick dan E. A. Adelberg. 2005. Mikrobiologi Untuk Profesi Kesehatan Edisi 4. Diterjemahkan oleh Bonang, G. Penerbit Buku Kesehatan. Jakarta.

Kaawoan P.T., Jemmy A. dan Krista VS. 2016. Uji Daya Hambat Ekstrak Buah Pala (Myristica fragrans Houtt.) terhadap Bakteri Penyebab Periodontitis Porphyromonas gingivalis secara In Vitro. Jurnal e-GiGi Vol 4, No 2 : 111 -114 .

Karima A. M. 2015. Uji Daya Antibakteri Ekstrak Etanol Kayu Siwak (Salvadora persica) terhadap Pertumbuhan Bakteri Porphyromonas gingivalis penyebab Gingivitis In Vitro. Skripsi S1. Universitas Muhammadiyah Surakarta. Surakarta.

Monalisa D., Handayani T. K. dan Sukmawati D. 2011. Daya Antibakteri Ekstrak Daun Tapak Liman (Elephantopus scaber L.) terhadap Staphylococcus aureus dan Salmonella typhi. Bioma Vol 9, No 2 : 13 - 20.

Nagariya A. K., A. K. Meena, D. Jain, B. P. Gupta, A. K. Yadav, M. R. Gupta, A. K. Pathak dan Neelam. 2010. Medicinal Plants Used in the Healing of Skin Diseases in Different Regions of India: A Review. International
Journal of Chemical and Analytical Science Vol 1, No 5 : 110-113.

Nasutiano H. 2007. Bakteri Penyebab Penyakit Peridontal. Interdental Vol 5, No $3: 11$ $-14$.

Newman M. G., Takei H. H., Klokkevold P. R. dan Sarranza F. A. 2012. Carranza's Clinical Periodontolog 11th ed. Saunders Elseviers. China.

Ngazizah F. N., Nuraeni E. dan Aisyah T. S. 2016. Potensi Daun Trembilungan (Begonia hirtella Link.) sebagai Antibakteri dan Antifungi. Biosfera Vol 33, No $3: 126$ - 133.

Ningsih A. P, Nurmiati dan Anthoni A. 2013. Uji Aktivitas Antibakteri Ekstrak Kental Tanaman Pisang Kepok Kuning (Musa paradisiaca Linn.) terhadap Staphylococcus aureus dan Escherichia coli. Jurnal Biologi Universitas Andalas Vol 2, No 3 : 207 $-213$.

Novianti D. 2015. Daya Hambat Ekstrak Buah Mengkudu (Morinda citrifolia) terhadap Bakteri Shigella Dysenteriae. Sainmatika Vol 12, No $1: 1-7$.

Ritna, A., Syariful, A., dan Akhmad K. 2016. Identifikasi Senyawa Flavonoid pada Fraksi Etil Asetat Benalu Batu (Begonia sp.) asal Kabupaten Morowali Utara. Galenika Journal of Pharmacy. Vol 2, No 2 : 83 - 89.

Samaranayake L. 2012. Essential Microbiology for Dentistry. Elsevier Limited. Churchill Livingstone.

Siregar H. M. 2017. The Conservation of Native, Lowland Indonesian Begonia Species (Begoniaceae) in Bogor Botanic Gardens. Biodiversitas Vol 18, No $1: 326-333$.

Siregar H., R. S. Purwantoro, Sudarmono dan A. Agusta. 2009. Pengungkapan Potensi Obat pada Tiga Jenis Begonia Terpilih (B. muricata Blume, $B$. multangula Blume, B. "Bacem Kebo") 
melalui Uji Antibakteri Escherichia coli dan Staphylococcus aureus secara In Vitro. Prosiding Seminar Nasional Sains II. 13 - 15 November. Bogor.

Sofrata A. H., Claesson R. L., Lingstrom P. K. dan Gustaffsson A. K. 2008. Strong Antibacterial Effect of Miswak Againts Oral Microorganisms Associated with Peroiodontitis and Caries. Journal Periodontal Vol 79, No 8.

Taufiq S, U. Yuniarni dan S. Hazar. 2015. Uji Aktivitas Antibakteri Ekstrak Etanol Biji Buah Pepaya (Carica papaya L.) terhadap Escherichia coli dan Salmonella thypi. Bandung: Prosiding Penelitian SPeSIA Unisba. Bandung.

Widagdo Y. dan Suntya K. 2007. Volatile Sulfur Compounds sebagai Penyebab Halitosis. Interdental Vol 5, No $3: 1$ 5.

Wiriadinata H., Girmansyah D., Hoover S. dan Hunter J. 2002. Kekayaan Begonia Taman Nasional Gunung Halimun. Berita Biologi Edisi Khusus Biodiversitas Taman Nasional Gunung Halimun Vol 6, No 1 : 91 - 97. 